\title{
California Current seascape influences juvenile salmon foraging ecology at multiple scales
}

\author{
Megan C. Sabal ${ }^{1, *}$, Elliott L. Hazen ${ }^{2}$, Steven J. Bograd ${ }^{2}$, R. Bruce MacFarlane ${ }^{3}$, \\ Isaac D. Schroeder ${ }^{2,4}$, Sean A. Hayes ${ }^{5}$, Jeffrey A. Harding ${ }^{3}$, Kylie L. Scales ${ }^{2,4,6}$, \\ Peter I. Miller ${ }^{7}$, Arnold J. Ammann ${ }^{3}$, Brian K. Wells ${ }^{3}$ \\ ${ }^{1}$ University of California Santa Cruz, Department of Ecology and Evolutionary Biology, Santa Cruz, CA 95060, USA \\ ${ }^{2}$ Environmental Research Division, Southwest Fisheries Science Center, National Marine Fisheries Service, NOAA, \\ Monterey, CA 93940, USA \\ ${ }^{3}$ Southwest Fisheries Science Center, National Marine Fisheries Service, NOAA, Santa Cruz, CA 95060, USA \\ ${ }^{4}$ Institute of Marine Sciences, University of California Santa Cruz, Santa Cruz, CA 95064, USA \\ ${ }^{5}$ Northeast Fisheries Science Center, National Marine Fisheries Service, NOAA, Woods Hole, MA 02543, USA \\ ${ }^{6}$ Global Change Ecology Research Group, School of Science and Engineering, University of the Sunshine Coast, \\ Maroochydore, QLD 4556, Australia \\ ${ }^{7}$ Remote Sensing Group, Plymouth Marine Laboratory, Plymouth PL1 3DH, UK
}

\begin{abstract}
Juvenile salmon Oncorhynchus spp. experience variable mortality rates during their first few months in the ocean, and high growth during this period is critical to minimize sizeselective predation. Examining links between the physical environment and foraging ecology is important to understand mechanisms that drive growth. These mechanisms are complex and include interactions among the physical environment, forage availability, bioenergetics, and salmon foraging behavior. Our objectives were to explore how seascape features (biological and physical) influence juvenile Chinook salmon $O$. tshawytscha foraging at annual and feedingevent scales in the California Current Ecosystem. We demonstrate that forage abundance was the most influential determinant of mean salmon stomach fullness at the annual scale, while at the feeding-event scale, fullness increased with greater cumulative upwelling during the $10 \mathrm{~d}$ prior and at closer distances to thermal fronts. Upwelling promotes nutrient enrichment and productivity, while fronts concentrate organisms, likely resulting in available prey to salmon and increased stomach fullness. Salmon were also more likely to consume krill when there was high prior upwelling, and switched to non-krill invertebrates (i.e. amphipods, decapods, copepods) in weaker upwelling conditions. As salmon size increased from 72-250 mm, salmon were more likely to consume fish, equal amounts of krill, and fewer non-krill invertebrates. Broad seascape processes determined overall prey availability and fullness in a given year, while fine- and meso-scale processes influenced local accessibility of prey to individual salmon. Therefore, processes occurring at multiple scales will influence how marine organisms respond to changing environments.
\end{abstract}

KEY WORDS: Salmon diets $\cdot$ Fullness $\cdot$ Krill $\cdot$ Upwelling $\cdot$ Fronts $\cdot$ Retention

\section{INTRODUCTION}

Interactions between the marine seascape and foraging ecology of higher order consumers can be complex and may be caused by processes at different

\footnotetext{
${ }^{*}$ Corresponding author: msabal@ucsc.edu
}

spatial and temporal scales (Embling et al. 2012, Bost et al. 2015). Juvenile Chinook salmon Oncorhynchus tshawytscha feed on a variety of prey organisms in the California Current Ecosystem (CCE), and the abundance and distribution of their prey are deter-

Outside the USA @ The U.S. Government 2020. Open Access under Creative Commons by Attribution Licence. Use, distribution and reproduction are unrestricted. Authors and original publication must be credited.

Publisher: Inter-Research · www.int-res.com 
mined by various physical oceanographic processes (Friedman et al. 2018). The links between ocean processes, biological productivity, and foraging ecology of meso-predators remain unclear but are important because they affect population dynamics of commercially and culturally valuable species.

Chinook salmon are important in California, and the first few months after juvenile salmon have entered the ocean are a critical period of high juvenile salmon mortality (Beamish \& Mahnken 2001, Duffy \& Beauchamp 2011). During this period, juvenile salmon feed opportunistically on diverse prey to gain energy quickly (MacFarlane 2010, Hertz et al. 2015). Especially important diet items include krill and juvenile rockfishes Sebastes spp. because they are energetically valuable and abundant, and therefore increase growth, body condition, and subsequently, adult returns (Wells et al. 2012). High early growth in the ocean during spring and summer helps salmon pass through the most vulnerable size classes, thereby reducing size-dependent mortality (Woodson et al. 2013, Claiborne et al. 2014). Thus, salmon foraging ecology during these early ocean months is an important mechanistic link to growth, survival, and population dynamics.

At the annual scale, the intensity and timing of coastal upwelling influence salmon prey abundance and composition in the $\mathrm{CCE}$, laying the foundation for salmon foraging decisions. Specifically, the location, size, and strength of the North Pacific High pressure system in late winter relates to the intensity of late-winter coastal upwelling (Schroeder et al. 2013). This early season upwelling preconditions areas with nutrients. Schroeder et al. (2013) defined a preconditioning upwelling index (PCUI) as the sum of positive daily mean upwelling indices through January and February. This preconditioning approximately 4 mo prior to juvenile salmon ocean entry influences abundances of important forage species that salmon consume (Black et al. 2011, Ralston \& Stewart 2013, Wells et al. 2016). The seasonality of coastal upwelling also influences prey availability to salmon when they enter the ocean. The spring transition in the CCE is the time period when the system switches from downwelling to upwelling, causing dramatic physical oceanographic changes with an abrupt increase in productivity (Lynn 2003). Salmon benefit from entering the ocean after the spring transition when prey are most available (Satterthwaite et al. 2014). Broad oceanographic processes dictate salmon prey abundance and composition, and subsequently influence juvenile salmon growth and survival (Fiechter et al. 2015, Henderson et al. 2019).
Although these broad seascape processes are undoubtably important, meso- and fine-scale processes may also affect salmon prey distribution and salmon foraging behavior (see Table 1). Local upwelling brings nutrient-rich water to the surface, which starts a process of biological succession subsequently increasing the abundance of salmon prey (GarcíaReyes et al. 2014). During relaxation events, currents weaken, waters warm, and prey are retained (Melton et al. 2009). Fronts can also impact the distribution of salmon prey through aggregation and heightened productivity (Sato et al. 2018). In marine ecosystems, animals have shown heightened foraging success when physical conditions concentrate prey (Embling et al. 2012, Heerah et al. 2013). Other physical attributes such as bottom topography, surface currents, temperature, and salinity can influence the occurrence and density of prey organisms (Santora et al. 2012) and affect foraging success; for example, when currents and turbidity decrease encounter rates with prey (Mackenzie et al. 1994). Furthermore, salmon foraging decisions could be context-dependent, as they balance tradeoffs between predation risk and energetic needs - both of which may be influenced by the environment (Hunsicker et al. 2011, Ahrens et al. 2012). These local seascape processes that influence salmon at the feeding-event scale can also have population-level consequences via survival (Woodson \& Litvin 2015, Sabal et al. 2016).

Here, we quantified how the seascape, at annual and foraging-event scales, influences Chinook salmon foraging ecology. First, we asked how does salmon stomach fullness relate to seascape conditions at broad spatial (e.g. regional) and temporal (e.g. annual) scales? Second, we asked how does salmon foraging ecology (fullness, presence/absence of krill, fish, or non-krill invertebrates in diets) relate to local seascape features at fine spatial (e.g. 1-10 km) and temporal (e.g. days) scales? We hypothesized that stronger and early winter upwelling will relate to higher mean annual salmon stomach fullness due to increased nutrient preconditioning and subsequently abundant salmon prey. We hypothesized that local features that drive productivity (recent upwelling) and concentrate salmon prey (fronts, shallow depths, turbulence, and thermocline depth) would increase individual salmon stomach fullness (see Table 1). We also expected local features to influence salmon diet composition due to different habitat associations of forage species. For example, krill associate with deep water, juvenile rockfish with cool water, and zooplankton with warm, relaxed water (Wing et al. 1998, Santora et al. 
2012, Friedman et al. 2018). Our biological hypotheses were that salmon diet would change ontogenetically to include more fish prey with size (Daly et al. 2009) and that stomach fullness would decrease with salmon density due to competition (Martinson et al. 2008). To test these hypotheses, we evaluated a series of models relating seascape variables to salmon stomach fullness and diet composition at both annual and event scales. We predicted that salmon foraging ecology relates to the availability of prey (quantity and composition), which is the result of the integration of ocean processes at various scales.

\section{MATERIALS AND METHODS}

\subsection{Salmon and diet collection}

The National Marine Fisheries Service, Southwest Fisheries Science Center (SWFSC) conducted ocean surveys in June and July from 1999-2016 (excluding 2006-2009) to collect juvenile salmon in their first ocean summer off the Central California coast, and starting in 2010, additionally along the northern California and southern Oregon coasts (Fig. 1). Most Chinook salmon we collected came from 2 life-history types, fall-run and spring-run, which enter the coastal ocean as juveniles during spring and summer before the salmon survey. Therefore, our findings may not be easily generalized to other salmon runs that emigrate during other periods. Chinook salmon were captured with a surface trawl (264 Nordic rope trawl) that samples the upper $20 \mathrm{~m}$ of the water column for $\sim 30$ min tows (Harding et al. 2011). Salmon were identified, measured for fork length (FL), and weighed before being frozen. Chinook salmon were later dissected, the entire stomachs (lining and contents) were weighed, and diet contents were sorted to the lowest taxonomic grouping possible. We grouped prey into 3 categories, fish, krill, and nonkrill invertebrates (amphipods, copepods, decapods), and considered the presence/absence of each group in individual salmon diets. Salmon caught in 2010 and 2011 had only the stomach contents weighed, not the entire stomachs. Therefore, we estimated the weight of their empty stomach using a seconddegree polynomial regression of the weight of empty stomachs by salmon FL from the other $12 \mathrm{yr}\left(\mathrm{R}^{2}=\right.$ $0.93, \mathrm{p}<0.001)$. We then added total weight of the stomach contents to the estimated empty stomach to represent total stomach weight. To increase our sample size in estimating fullness, we used total stomach weight (lining and contents) instead of using diet

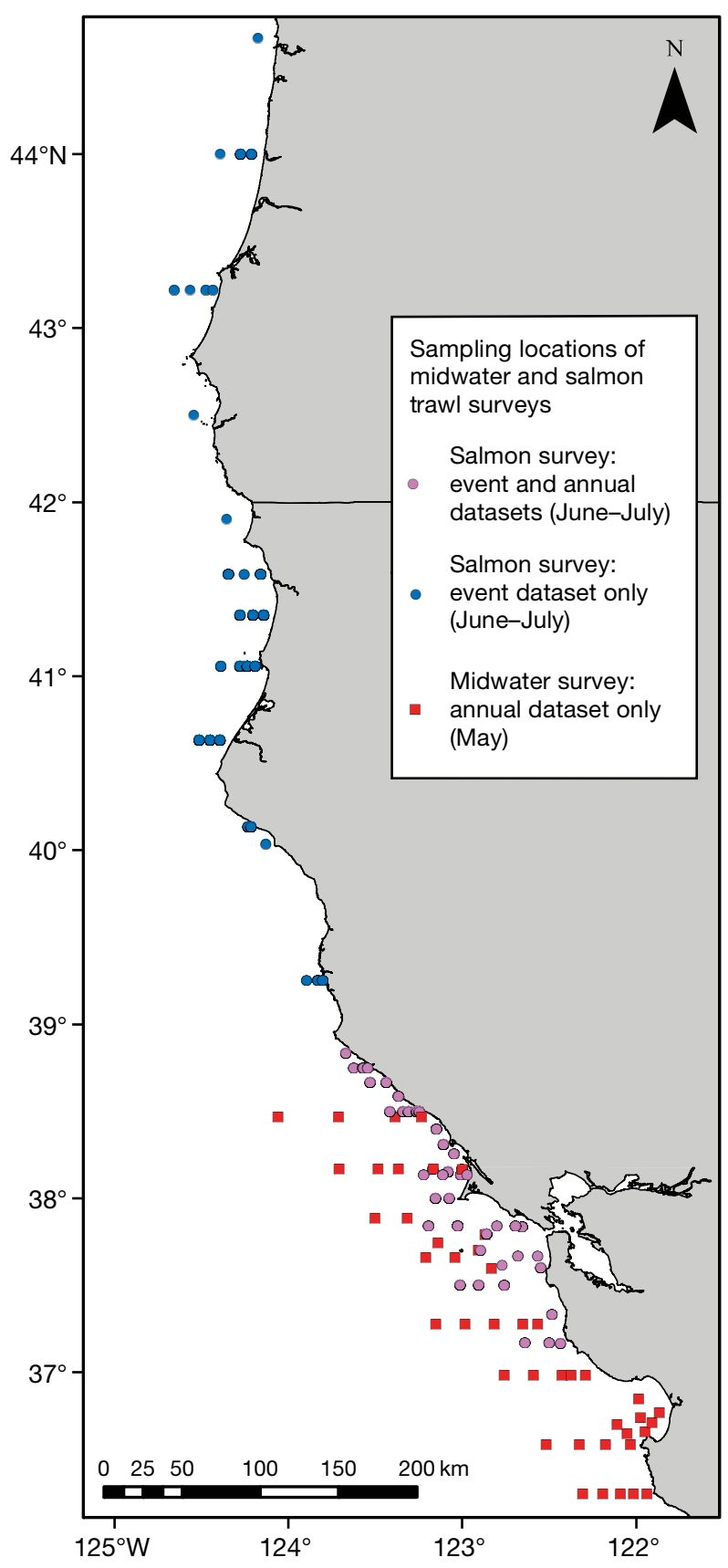

Fig. 1. Study area, northern California and southern Oregon coasts. Circles: sampling locations for salmon trawl surveys. Event scale analysis included all locations (blue and purple); annual scale analysis included southern locations only (purple). The FORAGE covariate in the annual analysis came from midwater trawl surveys (red squares)

contents only to calculate fullness. The index of stomach fullness followed the methods of Daly \& Brodeur (2015) as a measure of percent body weight that also accounts for the relationship of decreasing stomach fullness with increasing salmon size. 


$$
\text { Fullness }=\frac{\text { stomach weight }}{\text { salmon weight }- \text { stomach weight }} \times 100
$$

The fullness index was obtained from the residuals from the regression:

$$
\ln (\text { Fullness }) \sim \ln (\mathrm{FL})
$$

We only included juvenile Chinook salmon $<250 \mathrm{~mm} F L$, as these are likely to be of the cohort that entered the ocean that year (Hassrick et al. 2016). For annual models, we only included sampling stations from the geographic area that was sampled across all years - stations in central California south of $39^{\circ} \mathrm{N}$ latitude (Point Arena; Fig. 1). Event-scale models included the full data sets including the recent years extending north to Oregon (Fig. 1).

\subsection{Model covariates}

We characterized seascape processes, physical and biological ocean processes that vary over space and time, and related them to salmon foraging ecology on annual and event scales. On annual scales, regional and basin-wide oceanographic features interact to influence physical ocean conditions and productivity in the CCE. We considered spring-averaged (AprJun) monthly values of the Pacific Decadal Oscillation (PDO) to capture effects of broad temperature regimes when juvenile salmon first entered the ocean. Winter (Jan-Mar) monthly averages of the Multivariate El Niño Southern Oscillation Index (MEI) were used to indicate the presence of El Niño or La Niña conditions for the upcoming springsummer when salmon enter the ocean (Jacox et al. 2015b). Average annual values of the North Pacific Gyre Oscillation (NPGO) were considered as an index of broad-scale coastal productivity and transport (Di Lorenzo et al. 2008). To capture local-scale upwelling dynamics, we considered annual values for a PCUI at $39^{\circ} \mathrm{N}$ (Schroeder et al. 2013) and the date of spring transition (STDATE) as the day where the cumulative coastal upwelling index at $39^{\circ} \mathrm{N}$ first starts increasing (Bograd et al. 2009).

We estimated an annual measure of potential prey availability based on catches from the SWFSC midwater trawl survey, which occurs in May and June, 1-2 mo prior to the salmon trawl survey, and overlaps a similar spatial distribution off central California (Fig. 1). For specific forage groups found in salmon diets, we calculated $z$-scores to represent the relative abundance over the years salmon diets were sampled (Table S1 in the Supplement at www.int-res. com/articles/suppl/m634p159_supp.pdf). The trawl survey may not sample each forage group accurately for total abundance (e.g. it is better at sampling krill than certain fish), but relative abundances can still be useful indicators of general interannual variability for each forage group. The forage index (FORAGE) we developed was the sum of all forage group $z$-scores for each year, indicating if years had above (positive values) or below (negative values) relative abundances of prey groups that have been observed in salmon diets.

We examined event-scale variables hypothesized to influence local prey distribution due to unique habitat associations and, therefore, salmon foraging ecology (Table 1). The vertical structure of the water column was characterized using CTD and fluorometer casts taken at the same time as the net trawls. Sea surface temperature (SST), chlorophyll (CHL) at $2 \mathrm{~m}$, and thermocline depth (THERM; 'thermo.depth' in R package 'rLakeAnalyzer') were extracted from the CTD and fluorometer casts. THERM was the maximum change in temperature with respect to change in depth with weighted adjacent measurements (Winslow et al. 2015). At a slightly larger but still local spatial scale, we extracted values for wind speed from NOAA's National Centers for Environmental Information (NCEI) Blended Daily $0.25^{\circ}$ data set from the grid cell closest to the sampling location. The cube of wind speed was used as a measure of water turbulence (TURB) (Hetzel et al. 2018). We also extracted daily upwelling values from either 39, 42, or $45^{\circ} \mathrm{N}$ (whichever latitude was closest to the location of that salmon's capture) for the $10 \mathrm{~d}$ prior to salmon capture. Cumulative upwelling index (UP) was the sum of these 10 daily upwelling values unique to each fish based on date and location of capture. Wind and upwelling data used for the TURB and UP calculations were downloaded from ERDDAP (https://coastwatch.pfeg.noaa.gov/erddap).

Using ArcGIS 10.4 (ESRI), we averaged the bottom depth (DEP) in a $2 \mathrm{~km}$ radius around the location of each salmon's capture. We also calculated the distance of each salmon to the nearest thermal front (FRONT) using composite front maps, which use a front-detection algorithm based on Single-Image Edge Detection to delineate the complete surface manifestation of a frontal system from a series of partially cloud-obscured SST images (Cayula \& Cornillon 1992, Miller et al. 2015). The FRONT term used here was calculated per pixel over $1.1 \mathrm{~km}$ resolution, 7 d composite thermal front maps.

Biological variables considered in event-scale models included salmon FL, as foraging is expected to vary with ontogeny, and time of day (TIME) to cap- 
Table 1. Summary of event-scale seascape processes hypothesized to affect juvenile Chinook salmon foraging ecology and included as model covariates

\begin{tabular}{|c|c|c|c|c|}
\hline Covariate & Code & Data source & Resolution & Hypothesized effect \\
\hline Bottom depth (m) & DEP & NOAA/NCEI & $\begin{array}{l}3 \text { arc-second, } \\
2 \mathrm{~km} \text { radius }\end{array}$ & Shallow depth reduces prey refuge \\
\hline Distance to nearest thermal front $(\mathrm{km})$ & FRONT & $\begin{array}{l}\text { MoU Plymouth } \\
\text { Marine Laboratory }\end{array}$ & $\begin{array}{l}1.1 \mathrm{~km} \mathrm{pixel}^{-1}, \\
7 \mathrm{~d}^{-} \text {window }\end{array}$ & $\begin{array}{l}\text { Aggregation of prey; or acts as a 'wall' that } \\
\text { keeps forage on one side, e.g. inshore }\end{array}$ \\
\hline Turbulence $\left(\left[\mathrm{m} \mathrm{s}^{-1}\right]^{3}\right)$ & TURB & ERDDAP & $0.25^{\circ}$, daily & $\begin{array}{l}\text { Convergent flow aggregates prey; turbulence } \\
\text { decreases prey encounter rate }\end{array}$ \\
\hline $\begin{array}{l}\text { Cumulative upwelling index } \\
\left(\mathrm{m}^{3} \mathrm{~s}^{-1} \text { per } 100 \mathrm{~km} \text { coastline }\right)\end{array}$ & UP & ERDDAP & Daily & $\begin{array}{l}\text { Recent upwelling promotes aggregations of } \\
\text { prey in areas of increased nutrient influx }\end{array}$ \\
\hline Chlorophyll $\left(\mathrm{mg} \mathrm{m}^{-3}\right)$ & $\mathrm{CHL}$ & CTD & Tow & $\begin{array}{l}\text { High productivity can increase prey resources } \\
\text { and reduce visibility }\end{array}$ \\
\hline Thermocline depth (m) & THERM & CTD & Tow & Influence vertical distribution of prey \\
\hline Sea surface temperature $\left({ }^{\circ} \mathrm{C}\right)$ & TEMP & CTD & Tow & $\begin{array}{l}\text { Optimal temperature affects bioenergetic } \\
\text { efficiency; affects forage distribution }\end{array}$ \\
\hline Salmon fork length (mm) & FL & Cruise & Individual & Diet ontogeny \\
\hline Salmon density (count) & DEN & Cruise & Tow & $\begin{array}{l}\text { At high densities, competition reduces } \\
\text { fullness; salmon may aggregate when } \\
\text { feeding conditions are poor }\end{array}$ \\
\hline Time of tow (time format) & TIME & Cruise & Tow & Diel feeding patterns will affect fullness \\
\hline
\end{tabular}

ture diurnal feeding patterns. Salmon were only caught between 07:22 and 18:38 h (i.e. not over a full $24 \mathrm{~h}$ period), therefore TIME was not considered to be a circular variable. The relationship between stomach fullness and TIME was positive and mostly linear (Fig. S1) and was included in the model as an offset. The offset incorporated the relationship with TIME and allowed us to focus on the effects of other ocean covariates. We also included salmon density (DEN), which we defined as the number of conspecifics (Chinook < $250 \mathrm{~mm}$ FL) caught in the same tows that the stomach samples were taken, to assess potential effects of density dependence.

\subsection{Models}

We used generalized additive models (GAMs) to test for associations between salmon foraging response variables and seascape predictor variables (Table 2). We checked for highly correlated variables, and if variables had correlations greater than \pm 0.7 , we kept the variable whose relationship to salmon foraging and diet was believed to be strongest (Dormann et al. 2012). In our data, PDO was correlated with NPGO, and NPGO was correlated with FORAGE (Table S2); therefore, we included FORAGE and excluded NPGO and PDO from our model because FORAGE represents the closest biological link for salmon foraging ecology. Additionally, we used general variance inflation factors (GVIFs) to estimate multicollinearity, and kept only covariate combinations resulting in values well below the threshold of 10 (O'Brien 2007). We determined the best fit model using Akaike's information criterion adjusted for small sample size (AICc) model selection on every model combination using the function 'dredge' in the R package 'MuMIn' (Bartón 2015). We present the results of models with $\triangle \mathrm{AICC}<2$ and the relationships with covariates present in any of the top models. Post hoc analysis required examining the relationship between presence of all prey groups (krill, fish, non-krill invertebrates) and thermal fronts (FRONT), even if not included in the top models.

\subsubsection{Annual scale}

Our annual-scale analyses focused on evaluating the role of ocean productivity in salmon stomach fullness. To assess relationships with mean annual fullness of salmon stomachs, we used a GAM (R package 'mgcv'; Wood 2018) with a Gaussian distribution. The global model included FORAGE, PCUI, MEI, and STDATE, all with GVIF values < 2 (Table S2). Because the resulting GAM fit for the FORAGE covariate supported a mechanistic relationship where fullness increased with estimates of FORAGE until reaching 


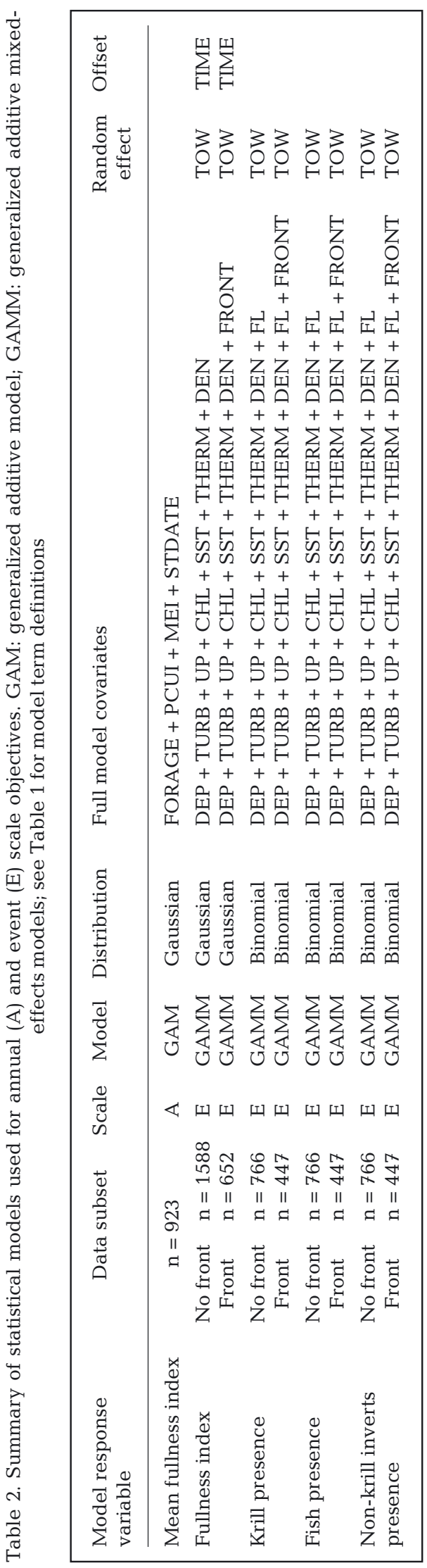

an asymptote, we also fit the fullness data to a mechanistic formula post hoc with an asymptotic shape with the formula:

$$
\text { Fullness index }=a \frac{b(\text { forage }-c)}{1+b(\text { forage }-c)}+\mathrm{d}
$$

We added 10 to the standardized forage index so all values were positive. We estimated parameter values $a, b, c, d$ from empirical data using maximum likelihood estimation with the 'mle2' function in the $\mathrm{R}$ package 'bbmle' (Bolker 2016). We excluded the year 2013 from analysis because it was an outlier for reasons which will be discussed later.

\subsubsection{Event scale}

Event-scale analyses addressed how local oceanographic conditions, ontogeny, and salmon density influenced salmon stomach fullness and diet composition. For event models, we used GAMs with mixedeffects (GAMM) in the R package 'gamm4' (Wood \& Scheipl 2015) to include tow as a random effect because multiple salmon were captured per tow. Main effects included DEP, TURB, UP, CHL, SST, THERM, FRONT, FL, and DEN (Table 2). Salmon prey were not collected concurrently with individual salmon and, therefore, those data were not available for this analysis. No variables we considered were highly correlated, and all GVIF values were $<2$. Fronts aggregate zooplankton and juvenile fish (Woodson \& Litvin 2015, Sato et al. 2018), and thus may affect stomach fullness. The FRONT data were only available for fewer than half of the salmon collected due to no available data in 2000, 2001, and 2015 and intermittent cloud cover in other years. Therefore, we first ran the event models without the FRONT data, including all salmon data points, and second, we included the FRONT data on the reduced data set (Table 2).

The fullness event-scale model used a Gaussian distribution, did not include FL because length was already incorporated into the fullness index, and additionally included TIME as an offset to incorporate the strong positive relationship between fullness and time of day (Fig. S1). For presence of prey group models, we used a binomial distribution with a logit link function (Table 2). The prey group models included FL to examine effects of ontogeny, while TIME was not included because diet items can stay in the stomach for over $24 \mathrm{~h}$ (Benkwitt et al. 2009). We log transformed variables DEP, CHL, THERM, DEN, and FRONT, and took the square root of TURB to stabilize variances to meet model assumptions. All 
analyses were conducted using $\mathrm{R}$ version 3.6.1 ( $\mathrm{R}$ Development Core Team 2019).

\section{RESULTS}

\subsection{Salmon and diets}

A total of 1588 juvenile Chinook salmon were captured between 1999 and 2016 (mean \pm SD FL: 155.6 \pm 39 ; range: $72-250 \mathrm{~mm}$ ). Although all salmon had fullness data, only some had diet samples sorted. Thus, different subsets of salmon were used in our analyses: mean annual fullness ( $\mathrm{n}=923)$, individual event-scale fullness ( $\mathrm{n}=1588$ ), and probability of prey groups $(\mathrm{n}=766)$. Juvenile salmon diets varied across years (Fig. S2). Main prey categories were krill and fish.

\subsection{Annual model}

The 11 sampling years included in the annual model were characterized by variation in biological and oceanographic conditions (Fig. S3). High FORAGE occurred in years of low values of the NGPO index but was less related to other annual variables (Table S2). Although not highly statistically correlated, years with high PCUI generally had an early STDATE (Fig. S3, Table S2). Mean salmon fullness also varied across years (mean $\pm \mathrm{SD}$ : $0.10 \pm 0.18$; range: -0.21 to 0.34). The single most important annual covariate that explained differences in mean salmon fullness through AICc model selection was FORAGE (Table 3; $\mathrm{R}^{2}=0.30, \mathrm{df}=3, \mathrm{AICC}=-2.0, \log \mathrm{Lik}=5.7$, weight of evidence $=0.35$ ). Post hoc analysis indicated that fullness followed a non-linear asymptotic relationship, although notably, salmon fullness in 2013 was much lower than what would have been expected from the model (Fig. 2).

Table 3. Summary of top mean annual fullness generalized additive models for juvenile Chinook salmon. AICc: Akaike's information criterion corrected for small sample sizes; $\triangle$ AICc: AIC difference from the best model. See Table 1 for model term abbreviations

\begin{tabular}{lcrrrrr}
$\begin{array}{l}\text { Top annual } \\
\text { fullness models }\end{array}$ & df & logLik & AICc & $\Delta$ AICc & weight & $\mathrm{R}^{2}$ \\
\hline FORAGE & 3 & 5.7 & -2.0 & 0 & 0.35 & 0.30 \\
NULL & 1 & 3.7 & -1.9 & 0.06 & 0.34 & 0.00 \\
MEI & 3 & 4.4 & 0.6 & 2.59 & 0.10 & 0.12 \\
FORAGE + MEI & 4 & 7.7 & 1.5 & 3.44 & 0.06 & 0.52 \\
\hline
\end{tabular}

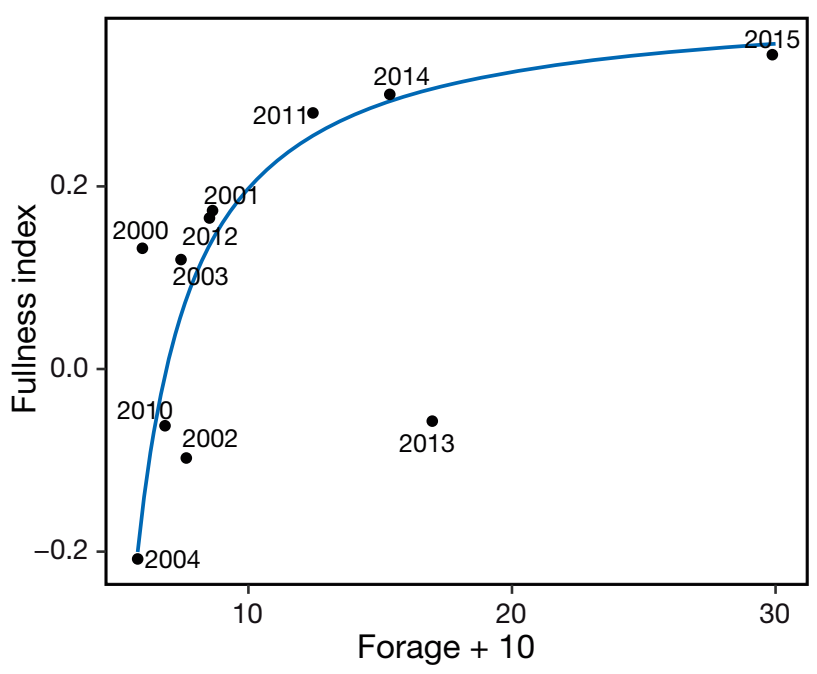

Fig. 2. Juvenile salmon mean annual fullness index is nonlinearly related to annual forage index

\subsection{Event models}

Event-scale seascape covariates varied across sampling events (i.e. survey tow; Table 4). Salmon fullness was examined with 2 separate data sets: one excluding the covariate FRONT with a sample size of 1588, and a second including FRONT with a sample size of 652. In both model sets, salmon exhibited higher stomach fullness under conditions of increased cumulative upwelling $10 \mathrm{~d}$ prior (Fig. 3). In the full data set, UP alone represented the top model (Table 5; $\mathrm{R}^{2}=0.18, \mathrm{df}=5, \mathrm{AICc}=1341, \log \mathrm{Lik}=$ -671.3 , weight of evidence $=0.28$ ). When a subset of the fullness data set was analyzed to include FRONT as a covariate, upwelling remained significant, and fullness increased nearer to thermal fronts and under high chlorophyll conditions (Table 5, Fig. $4 ; \mathrm{R}^{2}=0.20$, $\mathrm{df}=7, \mathrm{AICc}=638.1, \log \mathrm{Lik}=-318.4$, weight of evidence $=0.13)$.

Presence of prey group models were examined with 2 separate data sets: one excluding the covariate FRONT with a sample size of 766, and a second including FRONT with a sample size of 447. The top models explaining variation in the probability of krill in salmon diets included SST, DEP, and UP (Table 5; $\mathrm{R}^{2}=0.36, \mathrm{df}=8, \mathrm{AICc}=$ 733.8, $\log \mathrm{Lik}=-358.8$, weight of evidence $=0.39$ ). Krill was more likely to occur in salmon diets under conditions of high upwelling $10 \mathrm{~d}$ prior to sampling, cooler SST, and at locations of greater depths (Fig. 4). The same covariates were important in the top krill models in both data subsets. SST, DEP, and UP were more important explaining 
Table 4. Summary of raw data of annual- and event-scale seascape variables used in models. DOY: day of the year. See Table 1 for variable abbreviation definitions

\begin{tabular}{|c|c|c|c|c|c|}
\hline Variable & Model & Mean & $\mathrm{SD}$ & Range & $\begin{array}{c}\text { Data } \\
\text { transformation }\end{array}$ \\
\hline STDATE (DOY) & Annual & 42 (Feb 11) & 27.3 & $2(\operatorname{Jan} 2)-76($ Mar 17) & None \\
\hline PCUI $\left(\mathrm{m}^{3} \mathrm{~s}^{-1}\right.$ per $100 \mathrm{~km}$ coastline) & Annual & 2833.9 & 1798.3 & $315.7-6090.7$ & None \\
\hline Winter MEI (index) & Annual & 0.11 & 0.87 & -1.56 to 1.37 & None \\
\hline FORAGE (index) & Annual & 1.412 & 7.19 & -4.20 to 19.88 & None \\
\hline $\mathrm{DEP}(\mathrm{m})$ & Event & 80.84 & 121.35 & $24.37-606.65$ & $\operatorname{Ln}(x)$ \\
\hline FRONT (km) & Event & 64.04 & 83.89 & $0-254$ & $\operatorname{Ln}(x+1)$ \\
\hline TURB $\left(\left[\mathrm{m} \mathrm{s}^{-1}\right]^{3}\right)$ & Event & 229040.9 & 295710.2 & $1.00-1259712$ & $\sqrt{ }(x)$ \\
\hline UP $\left(\mathrm{m}^{3} \mathrm{~s}^{-1}\right.$ per $100 \mathrm{~km}$ coastline) & Event & 2090.12 & 369.18 & $1107-2867$ & None \\
\hline $\mathrm{CHL}\left(\mathrm{mg} \mathrm{m}^{-3}\right)$ & Event & 4.80 & 4.75 & $0-25.49$ & $\operatorname{Ln}(x+1)$ \\
\hline THERM (m) & Event & 8.83 & 7.92 & $1.5-39.46$ & $\operatorname{Ln}(x)$ \\
\hline TEMP $\left({ }^{\circ} \mathrm{C}\right)$ & Event & 11.80 & 1.22 & $8.91-16.04$ & None \\
\hline
\end{tabular}
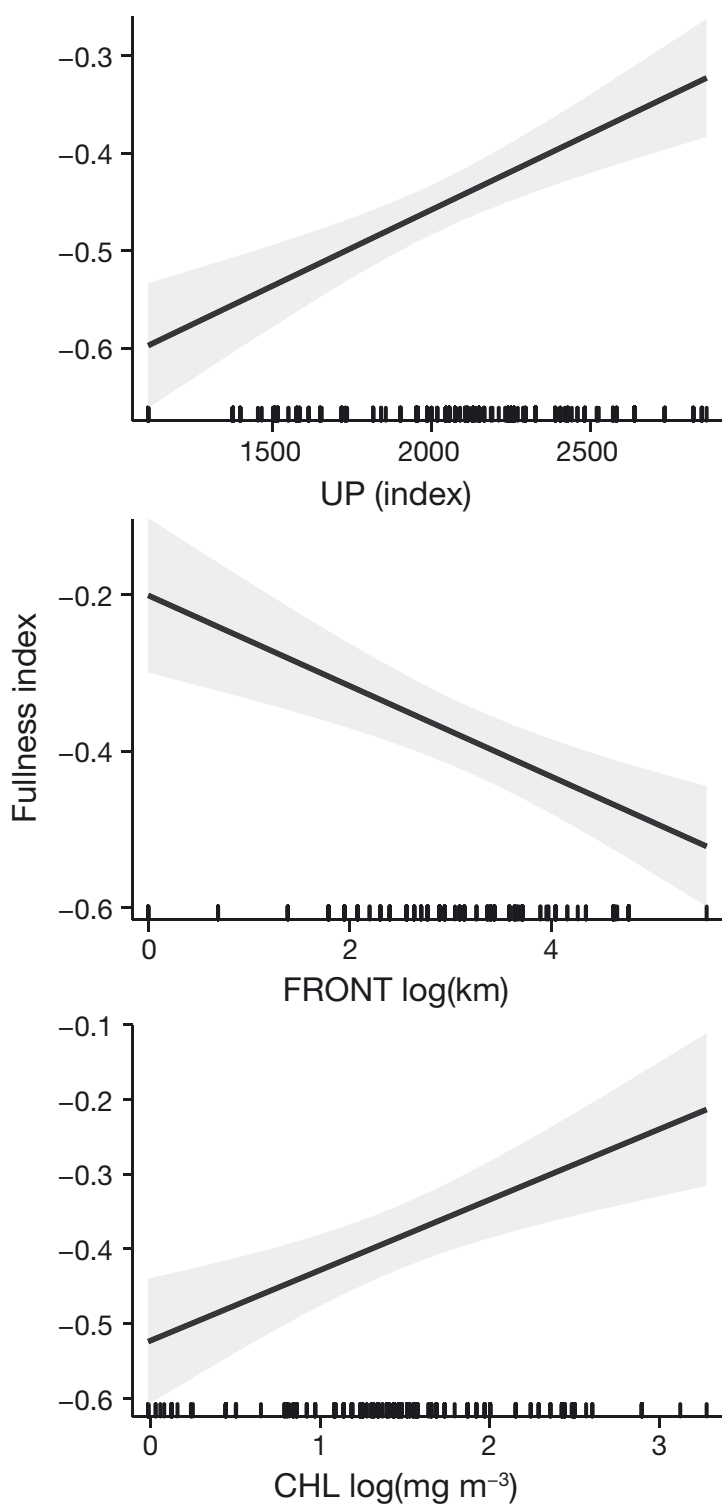

krill presence in salmon diets overall, however, salmon did consume more krill closer to thermal fronts (Fig. 4).

For the probability of fish occurring in salmon diets, there were 4 models with $\mathrm{AICc}<2$. The top model included only FL, indicating an increasing ontogenetic trend to consume fish prey (Fig. 5, Table 5; $\mathrm{R}^{2}=0.16, \mathrm{df}=4$, AICc $=929.1, \operatorname{logLik}=-460.5$, weight of evidence $=0.14$ ). SST and CHL were present in subsequent models, with fish more likely to occur in salmon diets under conditions of cool SST and high CHL (Fig. 5). In the data subset with FRONT, probability of salmon consuming fish prey had a non-linear relationship with FRONT. Fish were less common in salmon diets nearest and farthest away from thermal fronts (Fig. 5).

The top model for non-krill invertebrate prey (amphipods, copepods, and decapod larvae), consisted of FL, where smaller salmon consumed more invertebrates (Fig. 6, Table $5 ; \mathrm{R}^{2}=0.22, \mathrm{df}=4, \mathrm{AICc}=$ 773.8, $\log$ Lik $=-382.9$, weight of evidence $=0.17$ ). The next 2 models also had AICc $<2$ and included covariates UP and SST. Salmon were more likely to consume other invertebrates under conditions of low prior upwelling and cool SST (Fig. 6). FRONT was not an important variable explaining presence of non-krill invertebrates.

Fig. 3. Juvenile salmon fullness index across the range of (top) cumulative upwelling 10 days prior (UP), (middle) distance to the nearest thermal front (FRONT), and (bottom) surface chlorophyll (CHL), while keeping all other model covariates constant at average values. Solid black line: mean; gray areas: SE. Rug plots along the horizontal axes indicate the distribution of data points 
Table 5. Summary of top event-scale feeding models for juvenile Chinook salmon. All models are mixed-effects generalized additive models with individual tow as a random effect. See Table 1 for model term abbreviations

\begin{tabular}{|c|c|c|c|c|c|c|c|c|}
\hline $\begin{array}{l}\text { Model response } \\
\text { variable }\end{array}$ & $\begin{array}{l}\text { Data } \\
\text { subset }\end{array}$ & Top models & $\mathrm{df}$ & $\log \operatorname{Lik}$ & $\mathrm{AICc}$ & $\triangle \mathrm{AICc}$ & weight & $\mathrm{R}^{2}$ \\
\hline \multirow[t]{9}{*}{ Fullness index } & \multirow{3}{*}{$\begin{array}{l}\text { No front } \\
\mathrm{n}=1588\end{array}$} & UP & 5 & -671.3 & 1341 & 0 & 0.28 & 0.18 \\
\hline & & NULL & 3 & -671.4 & 1343 & 1.8 & 0.11 & 0.17 \\
\hline & & $\mathrm{UP}+\mathrm{CHL}$ & 7 & -672.9 & 1344 & 2.7 & 0.03 & 0.18 \\
\hline & \multirow{6}{*}{$\begin{array}{l}\text { Front } \\
\mathrm{n}=652\end{array}$} & UP + FRONT & 7 & -318.4 & 638.1 & 0 & 0.13 & 0.20 \\
\hline & & UP & 5 & -318.2 & 638.5 & 0.4 & 0.10 & 0.20 \\
\hline & & $\mathrm{UP}+\mathrm{CHL}$ & 7 & -319.0 & 638.9 & 0.8 & 0.08 & 0.20 \\
\hline & & NULL & 3 & -319.8 & 639.6 & 1.6 & 0.06 & 0.19 \\
\hline & & $\mathrm{UP}+\mathrm{CHL}+\mathrm{FRONT}$ & 9 & -319.8 & 639.9 & 1.8 & 0.05 & 0.20 \\
\hline & & FRONT & 5 & -320.3 & 641.1 & 3.0 & 0.03 & 0.19 \\
\hline \multirow{8}{*}{$\begin{array}{l}\text { Krill } \\
\text { presence/absence }\end{array}$} & \multirow{2}{*}{$\begin{array}{l}\text { No front } \\
\mathrm{n}=766\end{array}$} & $\mathrm{DEP}+\mathrm{SST}+\mathrm{UP}$ & 8 & -358.8 & 733.8 & 0 & 0.39 & 0.36 \\
\hline & & $\mathrm{DEP}+\mathrm{SST}$ & 6 & -362.5 & 737.0 & 3.2 & 0.08 & 0.35 \\
\hline & \multirow{6}{*}{$\begin{array}{l}\text { Front } \\
\mathrm{n}=447\end{array}$} & $\mathrm{DEP}+\mathrm{SST}$ & 6 & -192.3 & 396.9 & 0 & 0.18 & 0.36 \\
\hline & & $\mathrm{DEP}+\mathrm{UP}$ & 6 & -192.7 & 397.6 & 0.74 & 0.12 & 0.36 \\
\hline & & $\mathrm{DEP}+\mathrm{SST}+\mathrm{UP}$ & 8 & -190.9 & 398.1 & 1.21 & 0.10 & 0.37 \\
\hline & & DEP & 4 & -195.1 & 398.3 & 1.43 & 0.09 & 0.35 \\
\hline & & $\mathrm{DEP}+\mathrm{SST}+\mathrm{CHL}$ & 8 & -191.7 & 399.8 & 2.89 & 0.04 & 0.36 \\
\hline & & $\mathrm{DEP}+\mathrm{SST}+\mathrm{FRONT}$ & 8 & -192.3 & 400.9 & 4.0 & 0.02 & 0.36 \\
\hline \multirow[t]{8}{*}{ Fish presence/absence } & \multirow{5}{*}{$\begin{array}{l}\text { No front } \\
\mathrm{n}=766\end{array}$} & FL & 4 & -460.5 & 929.1 & 0 & 0.14 & 0.16 \\
\hline & & $\mathrm{FL}+\mathrm{SST}+\mathrm{CHL}$ & 8 & -456.5 & 929.1 & 0.03 & 0.13 & 0.17 \\
\hline & & $\mathrm{FL}+\mathrm{SST}$ & 6 & -458.7 & 929.6 & 0.5 & 0.11 & 0.16 \\
\hline & & $\mathrm{FL}+\mathrm{CHL}$ & 6 & -459.2 & 930.6 & 1.55 & 0.06 & 0.16 \\
\hline & & $\mathrm{FL}+\mathrm{DEP}$ & 6 & -459.8 & 931.8 & 2.77 & 0.03 & 0.16 \\
\hline & \multirow{3}{*}{$\begin{array}{l}\text { Front } \\
\mathrm{n}=447\end{array}$} & $\mathrm{FL}+\mathrm{SST}+\mathrm{FRONT}$ & 8 & -279.1 & 574.6 & 0 & 0.17 & 0.12 \\
\hline & & $\mathrm{FL}+\mathrm{SST}+\mathrm{FRONT}+\mathrm{CHL}$ & 10 & -277.9 & 576.4 & 1.81 & 0.07 & 0.13 \\
\hline & & FL & 4 & -284.5 & 577.0 & 2.47 & 0.05 & 0.10 \\
\hline \multirow{7}{*}{$\begin{array}{l}\text { Non-krill invertebrate } \\
\text { presence/absence }\end{array}$} & \multirow{4}{*}{$\begin{array}{l}\text { No front } \\
\mathrm{n}=766\end{array}$} & FL & 4 & -382.9 & 773.8 & 0 & 0.17 & 0.22 \\
\hline & & $\mathrm{FL}+\mathrm{UP}$ & 6 & -381.3 & 774.7 & 0.86 & 0.11 & 0.22 \\
\hline & & $\mathrm{FL}+\mathrm{SST}$ & 6 & -381.8 & 775.8 & 1.95 & 0.06 & 0.22 \\
\hline & & $\mathrm{FL}+\mathrm{UP}+\mathrm{SST}$ & 8 & -379.9 & 776.1 & 2.30 & 0.05 & 0.23 \\
\hline & \multirow{3}{*}{$\begin{array}{l}\text { Front } \\
\mathrm{n}=447\end{array}$} & $\mathrm{FL}+\mathrm{UP}+\mathrm{SST}$ & 8 & -189.5 & 395.3 & 0 & 0.20 & 0.32 \\
\hline & & $\mathrm{FL}+\mathrm{UP}+\mathrm{SST}+\mathrm{DEP}$ & 10 & -187.6 & 395.7 & 0.35 & 0.17 & 0.32 \\
\hline & & $\mathrm{FL}+\mathrm{UP}+\mathrm{SST}+\mathrm{FRONT}$ & 10 & -188.6 & 397.8 & 2.4 & 0.06 & 0.32 \\
\hline
\end{tabular}

\section{DISCUSSION}

Our study documented patterns in juvenile Chinook salmon foraging ecology linked to seascape processes at annual and foraging-event scales. Interannually, salmon had higher stomach fullness with increasing potential prey abundance. Locally, salmon had greater stomach fullness with greater cumulative upwelling during the $10 \mathrm{~d}$ prior to sampling and in closer proximity to thermal fronts, potentially due to local enrichment of upwelled waters and concentration of prey (García-Reyes et al. 2014, Sato et al. 2018). The presence of certain prey groups in salmon diets varied with the physical environment, suggesting either unique patterns of prey distribu- tion (Friedman et al. 2018) or that salmon prefer certain prey types in specific environments (Hunsicker et al. 2011, Ahrens et al. 2012). This paper makes important progress towards understanding the variation in salmon foraging ecology relative to seascape conditions at multiple scales during a period when growth and condition are critical.

\subsection{Inter-annual seascape influences on productivity and salmon fullness}

Forage abundance in early spring had the strongest inter-annual relationship to salmon stomach fullness in the summer. Salmon fullness increased 

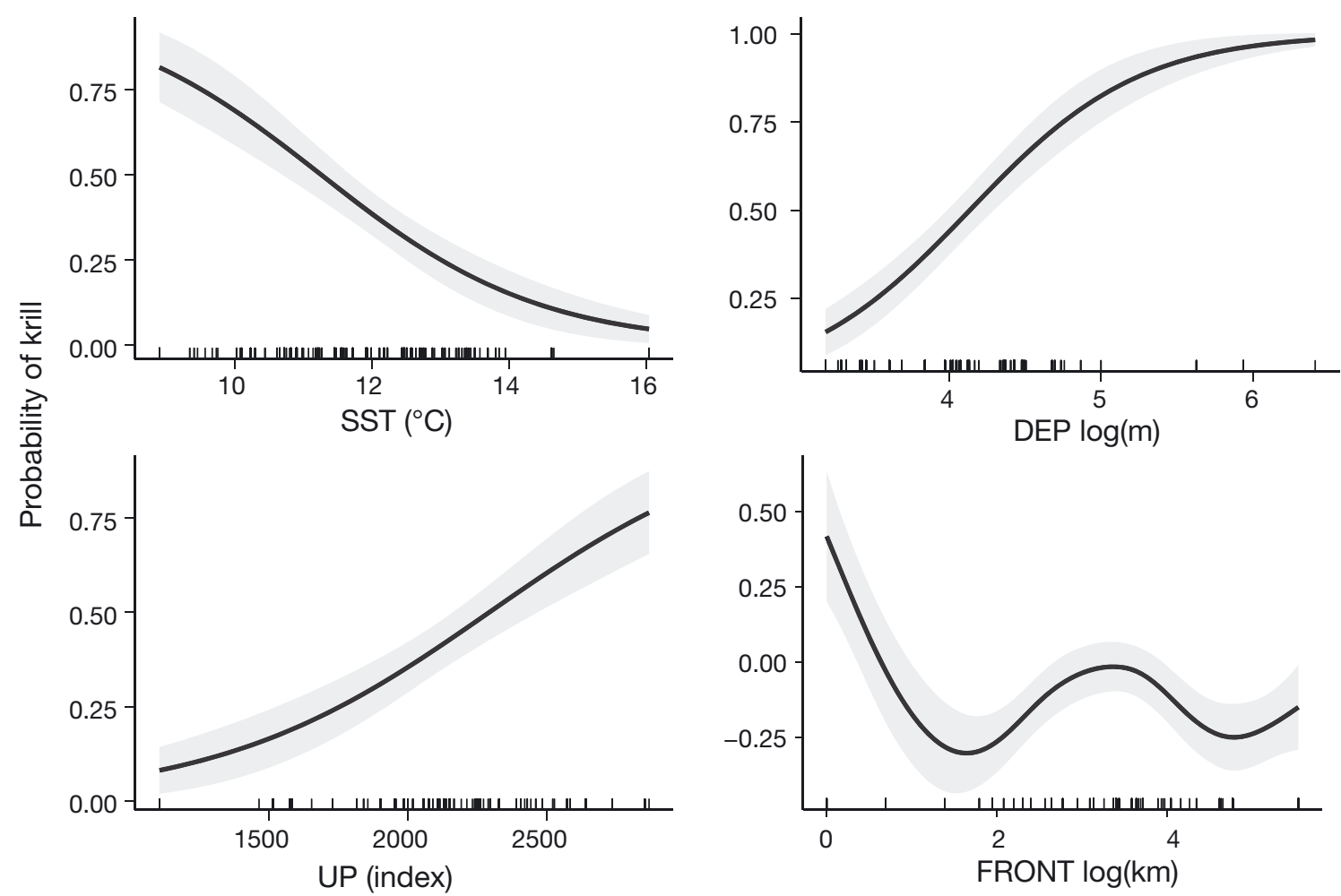

Fig. 4. Probability of krill presence in salmon diets across the range of (top left) sea surface temperature (SST), (top right) depth of sampling location (DEP), and (bottom left) cumulative upwelling $10 \mathrm{~d}$ prior (UP), and (bottom right) distance to nearest thermal front (FRONT), while keeping all other model covariates constant at average values. Solid black line: mean; gray areas: SE. Rug plots along the horizontal axes indicate the distribution of data points
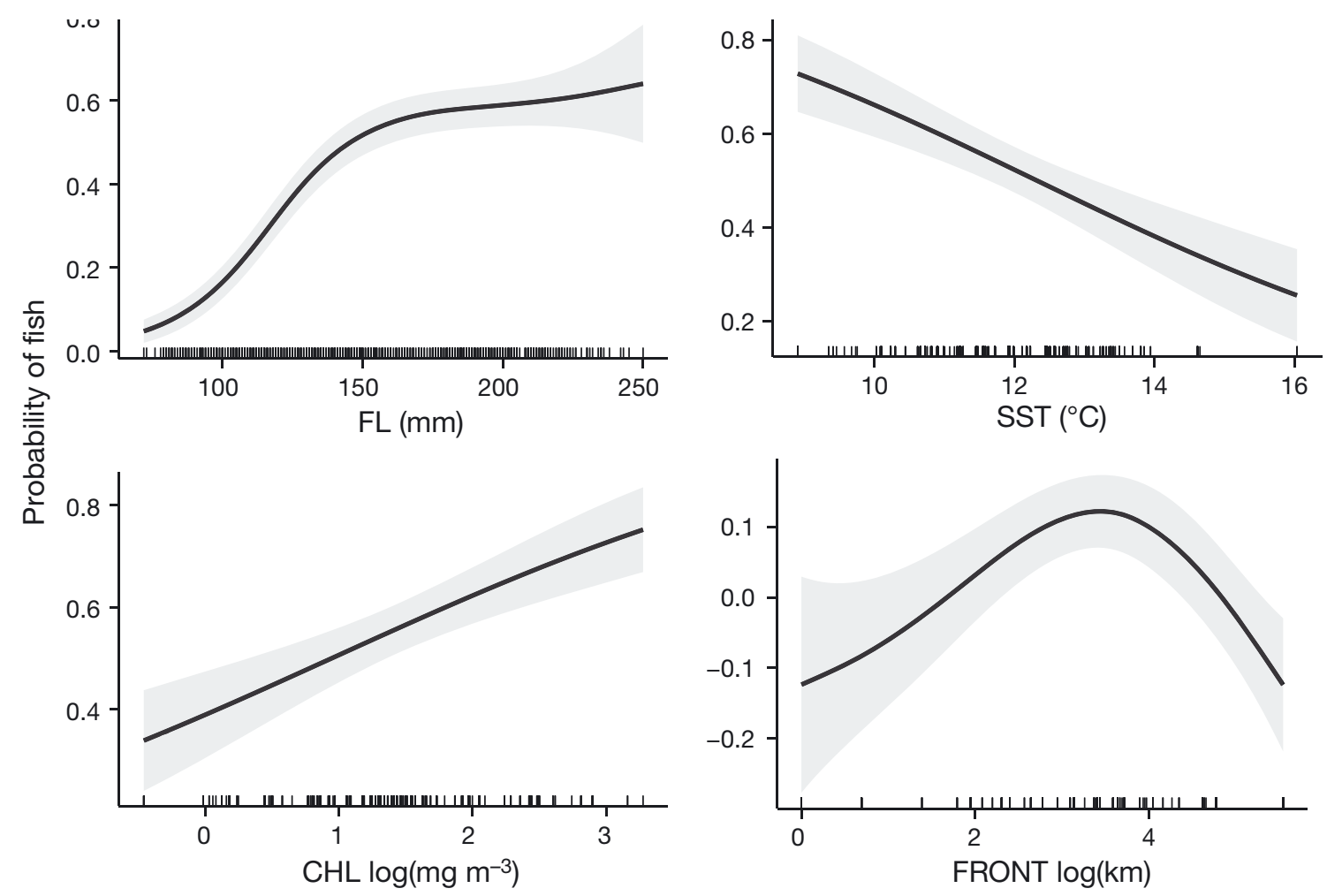

Fig. 5. Probability of fish presence in salmon diets across the range of (top left) fork length (FL), (top right) sea surface temperature (SST), and (bottom left) surface chlorophyll (CHL), and (bottom right) distance to nearest thermal front (FRONT), while keeping all other model covariates constant at average values. Solid black line: mean; gray areas: SE. Rug plots along the horizontal axes indicate the distribution of data points 

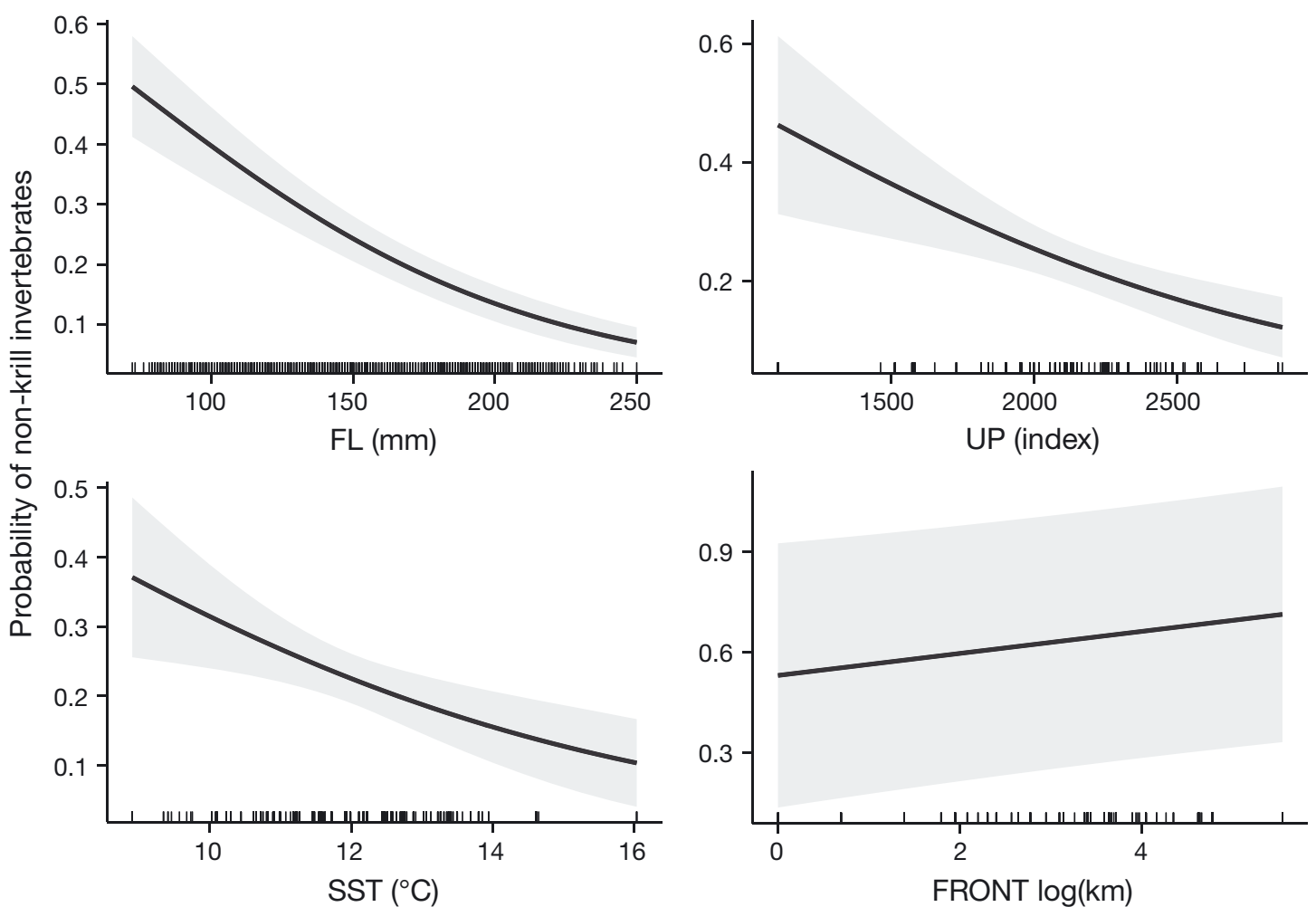

Fig. 6. Probability of non-krill invertebrate presence in salmon diets across the range of (top left) fork length (FL), (top right) cumulative upwelling $10 \mathrm{~d}$ prior (UP), and (bottom left) sea surface temperature (SST), and (bottom right) distance to nearest thermal front (FRONT), while keeping all other model covariates constant at average values. Solid black line: mean; gray areas: SE. Rug plots along the horizontal axes indicate the distribution of data points

asymptotically with forage. Forage abundance represents an integration of ocean processes at various scales (Jacox et al. 2015a) and is the most direct biological link to salmon fullness, which is likely why it was the top explanatory variable. Salmon are opportunistic feeders and can utilize a diverse prey base, which suggests why fullness related closely to overall forage abundance (Hertz et al. 2015).

The link between early upwelling, nutrient preconditioning, and abundant forage in the CCE has been well-supported and is likely the underlying process behind high forage in spring and, subsequently, salmon stomach fullness in summer (Black et al. 2011, Ralston \& Stewart 2013). However, in our annual data set PCUI was not linearly correlated with FORAGE or salmon fullness (Table S2). Increased upwelling benefits productivity of higher trophic levels only if prey organisms remain available to consumers on the continental shelf. Extremely high upwelling can increase advection of organisms off the shelf, which could explain why we did not observe a correlation between PCUI and FORAGE (Cury \& Roy 1989, Jacox et al. 2016a). In support of this idea, 2013 was characterized by extremely high levels of up- welling and an early spring transition date (Wells et al. 2013), and, in our annual analysis, salmon had much lower fullness than predicted by potential forage abundance estimated in spring. Our forage metric was derived from surveys in May-June, while salmon stomachs were sampled in July. Continued strong upwelling into summer may have advected forage off the shelf by the time salmon were sampled resulting in our observed low salmon stomach fullness in 2013.

Interestingly, in our years sampled, abundance of forage on the shelf in spring was higher in years with low NPGO, which differs from previous studies (Chenillat et al. 2012). This suggests that relationships observed among ocean and biological processes at broad spatial and temporal $(40+$ yr) scales can vary when examined over narrower regions and over shorter time periods (11 yr) (Chenillat et al. 2012).

Salmon fullness may have reached their maximum fullness in the high forage years of 2014 and 2015. These years were characterized by anomalously warm water, high productivity, and occurrence of unique prey assemblages in the northeast Pacific Ocean and CCE overall (Leising et al. 2015). Many 
top predators (e.g. birds, marine mammals) starved from these drastic physical and biological ocean changes (Cavole et al. 2016), and it is therefore somewhat perplexing that juvenile salmon had high stomach fullness during these years. Juvenile salmon feed on diverse prey items, which may allow them flexibility to respond to changes in the forage base. Salmon may also require more food in warm ocean regimes to sustain their higher metabolism and may actually feed more and have higher stomach fullness, despite growth and condition suffering (Daly \& Brodeur 2015). Interestingly, juvenile Chinook salmon in coastal Oregon and Washington in 2014 and 2015 had low stomach fullness, which differs from our observations in central and northern California (Daly et al. 2017). Despite regional warm water in these years, specific locations where our salmon were caught did not exhibit above average temperatures (Table S3). Coastal upwelling in the CCE may provide salmon temperature refugia from bioenergetic stress and allow them to maintain high levels of fullness if overall forage availability is high. The juvenile Chinook salmon cohorts that experienced the anomalously warm water during 2014 and 2015 had poor adult returns in 2016 and 2017 respectively (PFMC 2019). Therefore, despite high fullness, the anomalously warm water of 2014 and 2015 still may have negatively affected salmon, although drought conditions during freshwater out-migration in those years confounds the source of low cohort survival (Buchanan et al. 2018).

\subsection{Intra-annual seascape influences on salmon foraging ecology}

Larger-scale seascape processes determine the overall nutrient supply and prey abundance available to salmon, while finer-scale processes influence the local accessibility of that prey and impact individual salmon foraging ecology. We observed increased individual salmon stomach fullness with recent $(10 \mathrm{~d}$ cumulative) upwelling, high chlorophyll concentrations, and near thermal fronts. After recent upwelling, productive water with the associated biota can be retained during relaxation events and in geographically protected areas (Wing et al. 1998, Shanks et al. 2014). Thermal fronts also form between recently upwelled water and previously retained water masses (Sakuma et al. 2013). This interface of upwelled and relaxed water can result in increased chlorophyll inshore of the front, which aggregates zooplankton and higher trophic-level predators
(Woodson \& Litvin 2015, Sato et al. 2018). This combination of local enrichment from recent upwelling and concentration of prey near thermal fronts may create beneficial feeding opportunities for juvenile salmon.

Local seascape features also influenced which prey groups individual salmon consumed. Salmon consumed more fish and krill after recent upwelling and consumed more non-krill invertebrates in low upwelling regimes. Recently upwelled waters are cool with high chlorophyll concentrations, and support higher trophic-level organisms (García-Reyes et al. 2014). In our study, salmon were more likely to consume krill after recent upwelling, in cool and deep waters. These patterns align with known processes in the CCE coastal environment, as upwelling occurs along a number of deep canyons bordering and intersecting the shelf environment where krill is often concentrated adjacent to upwelling hotspots (Santora et al. 2018). Salmon were also more likely to consume fish prey in cool water with high chlorophyll. The most common fish prey species found in our salmon diets were juvenile rockfishes and sanddabs Citharichthys spp., and these species occur in cool upwelled waters; similar conditions to where they occurred in salmon diets (Ralston et al. 2013, Santora et al. 2014). Non-krill invertebrates (i.e. amphipods, decapods, copepods) were the only prey group that was more abundant in salmon diets following low recent upwelling. Relaxation events can be an important period for decapod larvae to settle along the coast, but larvae can be abundant during both relaxation and upwelling periods (Wing et al. 1998, Morgan et al. 2018). If non-krill invertebrates are relatively abundant across upwelling regimes and krill are more abundant after recent upwelling, our data suggest that juvenile salmon may preferentially feed on krill, and only consume non-krill invertebrates when other more profitable prey are not available. This hypothesis is consistent with studies conducted over broader spatial scales that show when a young cohort of krill Thysanoessa spinifera are unavailable as a result of poorer upwelling conditions in late-winter, the volume of crab larvae in salmon diets increased (Wells et al. 2012). Interestingly, krill, fish, and non-krill invertebrates were all more abundant in salmon diets in cool temperatures, possibly due to slower digestion rates, allowing all prey items to remain in salmon diets for a longer period.

Near thermal fronts, salmon were more likely to consume krill, less likely to consume fish, and had no relationship with non-krill invertebrates. Krill, non-krill zooplankton, and juvenile fishes have 
been observed to aggregate near fronts (LaraLopez et al. 2012, Sakuma et al. 2013, Sato et al. 2018). We may have randomly surveyed fronts where juvenile fish were not aggregated (although with 74 sampling occurrences this is unlikely), or juvenile salmon may have been preferentially feeding on krill near fronts. Fish are energetically valuable prey to salmon (Davis et al. 1998, Daly et al. 2010). However, salmon feeding on dense aggregations of krill may be especially advantageous, as in lunge-feeding whales (Goldbogen et al. 2011). The specific presence of $T$. spinifera in juvenile salmon diets has been shown to improve body condition more than the presence of other prey groups (Wells et al. 2012). Therefore, salmon may benefit from multiple foraging strategies, both consuming energetically valuable fish and targeting highly concentrated krill when available.

Juvenile salmon diet composition changed ontogenetically with salmon consuming fewer non-krill invertebrates, more fish, and equal amounts of krill with size. The shift from smaller, less energetically valuable invertebrates to larger, more energetically valuable fish prey is consistent with patterns of juvenile salmon observed in coastal Oregon (Daly et al. 2009). The energetic value of fish prey and gapelimitation likely drive this pattern. In this study, piscivory steadily increased over small sizes until remaining near 0.6 probability of occurrence over approximately $150 \mathrm{~mm}$ FL. Krill, however, remained a consistent prey group across salmon sizes. Therefore, both fish and krill are important prey to juvenile salmon - krill for their numerical abundance and positive relationship with fish condition (Wells et al. 2012) and fish for their energetic value and increasing occurrence of fish in diets with increasing fish size (Davis et al. 1998, Daly et al. 2010).

\section{CONCLUSIONS}

Our results show that broad and local seascape processes interact to influence salmon foraging ecology. Our hypothesis at the broad scale, that stronger, early upwelling would increase prey abundance and subsequently average salmon fullness, was partially supported. We found forage abundance to be the strongest predictor of salmon fullness, which is the result of the integration of many ocean processes including early upwelling. However, very high upwelling may advect available forage offshore. On the local scale, we observed support for our hypothesis that upwelling, which increases productivity, and thermal fronts, which concentrate prey, increased individual salmon fullness. Local features also influenced what prey groups salmon consumed, and patterns fit known habitat associations of forage and suggested that salmon preferred krill and fish prey over non-krill invertebrates. Salmon consumed more fish and less non-krill invertebrates with size, and we did not observe a reduction in stomach fullness with salmon density. Together, ocean processes at multiple scales influence the quantity and distribution of salmon prey, which represents the most direct biological link to salmon foraging ecology.

Broad processes affect overall nutrient input and productivity annually, while local processes modify the distribution of that productivity and are thus more important for species interactions. Salmon foraging decisions related to seascape processes could subsequently affect salmon survival via growth (Fiechter et al. 2015, Sabal et al. 2016, Henderson et al. 2019). Specific relationships between the environment and salmon foraging ecology will enable advances to modeling approaches, which can inform management strategies for improving resilience. Resilience in populations will become increasingly important as anomalous climate patterns increase in frequency, with possible disruption of known ecological links (Jacox et al. 2016b). The ability of salmon to adapt under changing conditions may rely on fine-scale behaviors to find and forage in productive conditions amidst a changing seascape.

Acknowledgements. This work was supported by California Department of Fish and Wildlife (00-1118) and Delta Science Fellowship with funding from State Water Contractors (A180850). We thank all the participants of the NOAA-NMFS Salmon Ocean Survey and Rockfish Recruitment and Ecosystem Assessment Survey, and crews of the vessels 'AR4 Jensen', 'Bell Shimada', 'Cassandra Anne', 'David Starr Jordan', 'Excalibur', 'Frosti', 'Irene's Way', 'Long Fin', 'Miller Feeman', 'Ocean Starr', 'Shana Rae', and 'Whitsel'. We thank C. Garza and his lab for providing genetic identification of salmon species.

\section{LITERATURE CITED}

Ahrens RNM, Walters CJ, Christensen V (2012) Foraging arena theory. Fish Fish 13:41-59

Bartón K (2015) R package MuMIn: multi-model inference. https://cran.r-project.org/package=MuMIn

Beamish RJ, Mahnken C (2001) A critical size and period hypothesis to explain natural regulation of salmon abundance and the linkage to climate and climate change. Prog Oceanogr 49:423-437

Benkwitt CE, Brodeur RD, Hurst TP, Daly EA (2009) Diel feeding chronology, gastric evacuation, and daily food consumption of juvenile chinook salmon in Oregon coastal waters. Trans Am Fish Soc 138:111-120 
Black BA, Schroeder ID, Sydeman WJ, Bograd SJ, Wells BK, Schwing FB (2011) Winter and summer upwelling modes and their biological importance in the California Current Ecosystem. Glob Change Biol 17:2536-2545

Bograd SJ, Schroeder I, Sarkar N, Qiu X, Sydeman WJ, Schwing FB (2009) Phenology of coastal upwelling in the California Current. Geophys Res Lett 36:L01602

Bolker B (2016) Maximum likelihood estimation and analysis with the bbmle package, v.1.0.20. https://cran. r-project.org/web/packages/bbmle/index.html

Bost CA, Cotté C, Terray P, Barbraud C and others (2015) Large-scale climatic anomalies affect marine predator foraging behaviour and demography. Nat Commun 6: 8220

*Buchanan RA, Brandes PL, Skalski JR (2018) Survival of juvenile fall-run Chinook salmon through the San Joaquin River Delta, California, 2010-2015. N Am J Fish Manage 38:663-679

Cavole LM, Demko AM, Diner RE, Giddings A and others (2016) Biological impacts of the 2013-2015 warm-water anomaly in the northeast Pacific: winners, losers, and the future. Oceanography (Wash DC) 29:273-285

* Cayula JF, Cornillon P (1992) Edge detection algorithm for SST images. J Atmos Ocean Technol 9:67-80

* Chenillat F, Riviére P, Capet X, Di Lorenzo E, Blanke B (2012) North Pacific Gyre Oscillation modulates seasonal timing and ecosystem functioning in the California Current upwelling system. Geophys Res Lett 39:L01606

Claiborne AM, Miller JA, Weitkamp LA, Teel DJ, Emmett RL (2014) Evidence for selective mortality in marine environments: the role of fish migration size, timing, and production type. Mar Ecol Prog Ser 515:187-202

* Cury P, Roy C (1989) Optimal environmental window and pelagic fish recruitment success in upwelling areas. Can J Fish Aquat Sci 46:670-680

Daly EA, Brodeur RD (2015) Warming ocean conditions relate to increased trophic requirements of threatened and endangered salmon. PLOS ONE 10:e0144066

Daly EA, Brodeur RD, Weitkamp LA (2009) Ontogenetic shifts in diets of juvenile and subadult coho and Chinook salmon in coastal marine waters: important for marine survival? Trans Am Fish Soc 138:1420-1438

Daly EA, Benkwitt CE, Brodeur RD, Litz MNC, Copeman LA (2010) Fatty acid profiles of juvenile salmon indicate prey selection strategies in coastal marine waters. Mar Biol 157:1975-1987

Daly E, Brodeur R, Auth T (2017) Anomalous ocean conditions in 2015: impacts on spring Chinook salmon and their prey field. Mar Ecol Prog Ser 566:169-182

Davis ND, Myers KW, Ishida Y (1998) Caloric value of highseas salmon prey organisms and simulated salmon ocean growth and prey consumption. NPAFC Bull 1:146-162

*Di Lorenzo E, Schneider N, Cobb KM, Franks PJS and others (2008) North Pacific Gyre Oscillation links ocean climate and ecosystem change. Geophys Res Lett 35: L08607

* Dormann CF, Schymanski SJ, Cabral J, Chuine I and others (2012) Correlation and process in species distribution models: bridging a dichotomy. J Biogeogr 39:2119-2131

* Duffy EJ, Beauchamp DA (2011) Rapid growth in the early marine period improves the marine survival of Chinook salmon (Oncorhynchus tshawytscha) in Puget Sound, Washington. Can J Fish Aquat Sci 68:232-240

Embling CB, Illian J, Armstrong E, van der Kooij J, Sharples J, Camphuysen KCJ, Scott BE (2012) Investigating fine- scale spatio-temporal predator-prey patterns in dynamic marine ecosystems: a functional data analysis approach. J Appl Ecol 49:481-492

*Fiechter J, Huff DD, Martin BT, Jackson DW and others (2015) Environmental conditions impacting juvenile Chinook salmon growth off central California: an ecosystem model analysis. Geophys Res Lett 42:2910-2917

Friedman WR, Santora JA, Schroeder ID, Huff DD, Brodeur RD, Field JC, Wells BK (2018) Environmental and geographic relationships among salmon forage assemblages along the continental shelf of the California Current. Mar Ecol Prog Ser 596:181-198

*García-Reyes M, Largier JL, Sydeman WJ (2014) Synopticscale upwelling indices and predictions of phyto- and zooplankton populations. Prog Oceanogr 120:177-188

*Goldbogen JA, Calambokidis J, Oleson E, Potvin J, Pyenson ND, Schorr G, Shadwick RE (2011) Mechanics, hydrodynamics and energetics of blue whale lunge feeding: efficiency dependence on krill density. J Exp Biol 214: 131-146

Harding JA, Ammann AJ, MacFarlane RB (2011) Regional and seasonal patterns of epipelagic fish assemblages from the central California Current. Fish Bull 109: $261-281$

* Hassrick JL, Henderson MJ, Huff DH, Sydeman WJ and others (2016) Early ocean distribution of juvenile Chinook salmon in an upwelling ecosystem. Fish Oceanogr 25: 133-146

* Heerah K, Andrews-Goff V, Williams G, Sultan E, Hindell M, Patterson T, Charrassin JB (2013) Ecology of Weddell seals during winter: influence of environmental parameters on their foraging behaviour. Deep Sea Res II 88-89:23-33

*Henderson M, Fiechter J, Huff DD, Wells BK (2019) Spatial variability in ocean-mediated growth potential is linked to Chinook salmon survival. Fish Oceanogr 28:334-344

* Hertz E, Trudel M, Brodeur RD, Daly EA and others (2015) Continental-scale variability in the feeding ecology of juvenile Chinook salmon along the coastal Northeast Pacific Ocean. Mar Ecol Prog Ser 537:247-263

*Hetzel Y, Pattiaratchi C, Mihanovi H (2018) Exchange flow variability between hypersaline Shark Bay and the ocean. J Mar Sci Eng 6:65

*Hunsicker ME, Ciannelli L, Bailey KM, Buckel JA and others (2011) Functional responses and scaling in predatorprey interactions of marine fishes: contemporary issues and emerging concepts. Ecol Lett 14:1288-1299

Jacox MG, Bograd SJ, Hazen EL, Fiechter J (2015a) Sensitivity of the California Current nutrient supply to wind, heat, and remote ocean forcing. Geophys Res Lett 42: 5950-5957

Jacox MG, Fiechter J, Moore AM, Edwards CA (2015b) ENSO and the California Current coastal upwelling response. J Geophys Res Oceans 120:1691-1702

Jacox MG, Hazen EL, Bograd SJ (2016a) Optimal environmental conditions and anomalous ecosystem responses: constraining bottom-up controls of phytoplankton biomass in the California Current System. Sci Rep 6:27612

Jacox MG, Hazen EL, Zaba KD, Rudnick DL, Edwards CA, Moore AM, Bograd SJ (2016b) Impacts of the 2015-2016 El Niño on the California Current System: early assessment and comparison to past events. Geophys Res Lett 43:7072-7080

* Lara-Lopez AL, Davison P, Koslow JA (2012) Abundance and community composition of micronekton across a front off Southern California. J Plankton Res 34:828-848 
Leising AW, Schroeder ID, Bograd SJ, Abell J (2015) State of the California Current 2014-15: impacts of the warmwater 'Blob'. CCOFI Rep 56:31-68

Lynn RJ (2003) Seasonal renewal of the California Current: the spring transition off California. J Geophys Res 108:3279

MacFarlane RB (2010) Energy dynamics and growth of Chinook salmon (Oncorhynchus tshawytscha) from the Central Valley of California during the estuarine phase and first ocean year. Can J Fish Aquat Sci 67:1549-1565

Mackenzie BR, Miller TJ, Cyr S, Leggett WC (1994) Evidence for a dome-shaped relationship between turbulence and larval fish ingestion rates. Limnol Oceanogr 39:1790-1799

Martinson EC, Helle JH, Scarnecchia DL, Stokes HH (2008) Density-dependent growth of Alaska sockeye salmon in relation to climate-oceanic regimes, population abundance, and body size, 1925 to 1998. Mar Ecol Prog Ser 370:1-18

Melton C, Washburn L, Gotschalk C (2009) Wind relaxations and poleward flow events in a coastal upwelling system on the central California coast. J Geophys Res 114:C11016

Miller PI, Scales KL, Ingram SN, Southall EJ, Sims DW (2015) Basking sharks and oceanographic fronts: quantifying associations in the north-east Atlantic. Funct Ecol 29:1099-1109

Morgan SG, Miller SH, Robart MJ, Largier JL (2018) Nearshore larval retention and cross-shelf migration of benthic crustaceans at an upwelling center. Front Mar Sci 5:161

* O'Brien RM (2007) A caution regarding rules of thumb for variance inflation factors. Qual Quant 41:673-690

PFMC (Pacific Fishery Management Council) (2019) Review of 2018 ocean salmon fisheries: stock assessment and fishery evaluation document for Pacific coast salmon fishery management plan. Pacific Fishery Management Council, Portland, OR

R Development Core Team (2019) R: a language and environment for statistical computing. R Foundation for Statistical Computing, Vienna

Ralston S, Stewart IJ (2013) Anomalous distributions of pelagic juvenile rockfish on the US west coast in 2005 and 2006. CCOFI Rep 54:1-12

Ralston S, Sakuma KM, Field JC (2013) Interannual variation in pelagic juvenile rockfish (Sebastes spp.) abundance - going with the flow. Fish Oceanogr 22:288-308

Sabal MC, Huff DD, Henderson MJ, Fiechter J, Harding JA, Hayes SA (2016) Contrasting patterns in growth and survival of Central Valley fall run Chinook salmon related to hatchery and ocean conditions. Environ Biol Fishes 99: 949-967

Sakuma K, Bjorkstedt E, Ralston S (2013) Distribution of pelagic juvenile rockfish (Sebastes spp.) in relation to temperature and fronts off Central California. CCOFI Rep 54:167-179

Santora JA, Field JC, Schroeder ID, Sakuma KM, Wells BK, Sydeman WJ (2012) Spatial ecology of krill, micronekton and top predators in the central California Current: implications for defining ecologically important areas. Prog Oceanogr 106:154-174

Editorial responsibility: Stylianos Somarakis, Heraklion, Greece
Santora JA, Schroeder ID, Field JC, Wells BK, Sydeman WJ (2014) Spatio-temporal dynamics of ocean conditions and forage taxa reveals regional structuring of seabirdprey relationships. Ecol Appl 24:1730-1747

Santora JA, Zeno R, Dorman JG, Sydeman WJ (2018) Submarine canyons represent an essential habitat network for krill hotspots in a Large Marine Ecosystem. Sci Rep 8: 7579

K Sato M, Barth JA, Benoit-Bird KJ, Pierce SD, Cowles TJ, Brodeur RD, Peterson WT (2018) Coastal upwelling fronts as a boundary for planktivorous fish distributions. Mar Ecol Prog Ser 595:171-186

Satterthwaite WH, Carlson SM, Allen-Moran SD, Vincenzi S, Bograd SJ, Wells BK (2014) Match-mismatch dynamics and the relationship between ocean-entry timing and relative ocean recoveries of Central Valley fall run Chinook salmon. Mar Ecol Prog Ser 511:237-248

Schroeder ID, Black BA, Sydeman WJ, Bograd SJ, Hazen EL, Santora JA, Wells BK (2013) The North Pacific High and wintertime pre-conditioning of California current productivity. Geophys Res Lett 40:541-546

* Shanks AL, Morgan SG, MacMahan J, Reniers AJHM and others (2014) Onshore transport of plankton by internal tides and upwelling-relaxation events. Mar Ecol Prog Ser 502:39-51

Wells BK, Santora JA, Field JC, MacFarlane RB, Marinovic BB, Sydeman WJ (2012) Population dynamics of Chinook salmon Oncorhynchus tshawytscha relative to prey availability in the central California coastal region. Mar Ecol Prog Ser 457:125-137

Wells BK, Schroeder ID, Santora JA, Hazen EL and others (2013) State of the California Current 2012-2013: no such thing as an 'average' year. CCOFI Rep 54:37-71

*Wells B, Santora J, Schroeder I, Mantua N, Sydeman W, Huff D, Field J (2016) Marine ecosystem perspectives on Chinook salmon recruitment: a synthesis of empirical and modeling studies from a California upwelling system. Mar Ecol Prog Ser 552:271-284

*Wing SR, Botsford LW, Ralston SV, Largier JL (1998) Meroplanktonic distribution and circulation in a coastal retention zone of the northern California upwelling system. Limnol Oceanogr 43:1710-1721

Winslow L, Read J, Woolway R, Brentrup J and others (2015) R package 'rLakeAnalyzer'. https://cran.r-project.org/ package=rLakeAnalyzer

Wood S (2018) R package 'mgcv'. https://cran.r-project.org/ package $=$ mgcv

Wood S, Scheipl F (2015) R package 'gamm4'. https://cran. r-project.org/package $=$ gamm 4

WWoodson CB, Litvin SY (2015) Ocean fronts drive marine fishery production and biogeochemical cycling. Proc Natl Acad Sci USA 112:1710-1715

*Woodson LE, Wells BK, Weber PK, MacFarlane RB, Whitman GE, Johnson RC (2013) Size, growth, and origindependent mortality of juvenile Chinook salmon Oncorhynchus tshawytscha during early ocean residence. Mar Ecol Prog Ser 487:163-175

Submitted: June 11, 2019; Accepted: November 5, 2019 Proofs received from author(s): January 14, 2020 